SCIREA Journal of Physics

ISSN: $2706-8862$

http://www.scirea.org/journal/Physics

September 5, 2021

SCIREA

Volume 6, Issue 5, October 2021

\title{
Core Flooding Experiment to Increase Recovery Factor Using "U-Champ" Biosurfactant
}

\section{Joko Pamungkas', Harry Budiharjo Sulistyarso","*, Indah Widiyaningsih', Hanqenina Damayanti $^{1}$}

${ }^{1}$ Department of Petroleum Engineering, Faculty of Mineral Technology, Universitas Pembangunan Nasional "Veteran" Yogyakarta, J1. Padjajaran (Lingkar Utara) Condongcatur, Yogyakarta 55283, Indonesia

*Corresponding author: harry_hb@upnyk.ac.id

\begin{abstract}
Increasing oil recovery factor can be done by draining the residual oil in the reservoir (Sor), by using Microbial Enhanced Oil Recovery (MEOR). This research was conducted using "UChamp" biosurfactants which derived from microorganisms that can reduce oil viscosity and interfacial tension (IFT) between oil and brine. The aims of this study are to analyze the effect of adding biosurfactant to changes reservoir fluid characteristics (viscosity and IFT) and to increase recovery factor. The tests on fluids include measurements of density, viscosity, and IFT carried out with concentrations of "U-Champ" biosurfactant $2.5 \%, 5 \%$, $7.5 \%$, and $10 \%$. The results obtained from this study are the increase in the oil density value from $0.8761 \mathrm{gr} / \mathrm{cc}(0 \%$ "U-Champ" concentration) to $0.9162 \mathrm{gr} / \mathrm{cc}(10 \%)$. Decreased oil viscosity value from $7.48 \mathrm{cp}$ to $4.10 \mathrm{cp}$ at $36.5^{\circ} \mathrm{C}$ and from $1.64 \mathrm{cp}$ to $0.58 \mathrm{cp}$ at $80^{\circ} \mathrm{C}$ at concentration of "U-Champ" 7.5\%. Decreased of IFT value by $12.93 \mathrm{mN} / \mathrm{m}(0 \%)$ to 5.80 $\mathrm{mN} / \mathrm{m}(7.5 \%)$ at $36.5^{\circ} \mathrm{C}$, and an IFT value of $9.83(0 \%) \mathrm{mN} / \mathrm{m}$ becomes $2.86 \mathrm{mN} / \mathrm{m}(7.5 \%)$ at
\end{abstract}


$80^{\circ} \mathrm{C}$. Based on core flooding experiment obtained $1.8 \mathrm{cc}$ OOIP, then showed an increase in $\mathrm{RF}$ value after injection of "U-Champ" biosurfactant from $44.44 \%$ (water flooding) to $81.67 \%$ (injection of "U-Champ" biosurfactant after 48 hours soaking time).

Keywords : Biosurfactant, Interfacial Tension, Recovery Factor, Viscosity

\section{Introduction}

In the primary and secondary recovery stages, oil cannot be completely drained, this is because there is still residual oil left or trapped in the reservoir rock matrix. Only hydrocarbons that naturally rise to the surface or those that require artificial lift are eligible for primary oil recovery. Water and gas injection are used in secondary recovery to dispense with the oil and drive it to the surface[1]. Moreover, microbial injection is one of the EOR methods (tertiary recovery stages) or well known as Microbial Enhanced Oil Recovery (MEOR). MEOR is a group of techniques that utilize microorganisms and their metabolic products to increase oil recovery from reservoir rock [2]. Furthermore, microorganisms in the reservoir are expected to be able to produce bioproducts that can change the characteristics of the oil as well as reservoir rock, which will help trapped oil being produced to the surface [3]. Additionally, one of the microbial bioproducts in MEOR is a biosurfactant. In other words, the changes of the characteristics might include decreasing the value of the IFT between oil and brine and oil viscosity [4]. From this, it can improve the sweeping efficiency, so that the oil in the reservoir will be easier to drain flow to the surface. Finally, it can increase the amount of oil in the core flooding experiment.

\section{Basic Theory}

\subsection{Biosurfactant}

Biosurfactants are amphipathic molecules with both hydrophilic and hydrophobic components. Biosurfactants are produced by hydrocarbons by utilizing microorganisms, through surface activity. These molecules can reduce surface tension $(\sigma)$, critical micelle concentration (CMC), and interfacial tension (IFT) in both aqueous solutions and hydrocarbon mixtures [5]. Based on their molecular size, biosurfactants can be divided into 
low molecular weight and high molecular weight biosurfactants. Glycolipids such as rhamnose and sophorolipids, and lipopeptides such as surfactin and polymyxin are low molecular weight biosurfactants, which function to reduce surface tension and interfacial tension. Meanwhile, high molecular weight biosurfactants such as lipoproteins, lipopolysaccharides, and amphipathic polysaccharides are very effective in stabilizing oil-inwater emulsions [6].

The mechanism of decreasing the interfacial tension itself can be observed from the mechanism of penetration of biosurfactant molecules into the hydrophilic (the part that reacts strongly with water molecules) and hydrophobic (the part of the molecule that moves away from water molecules and reacts slightly with water molecules) phases. The head of the hydrophilic biosurfactant will enter the hydrophilic phase which in this case is water, then the hydrophobic tail will enter the hydrophobic phase, which is oil.

The decreased interfacial tension value can mobilize oil that cannot be pushed by the water injection process. The flow of the oil-in-water emulsion that is formed along with the decrease in the oil-water IFT will increase the mobility ratio until the biosurfactant dilutes to the rock pore walls [7]. The addition of biosurfactants can reduce the value of oil viscosity because biosurfactants can degrade the heavy fraction of hydrocarbons. With the degradation of the heavy fraction, the long oil chain will be reduced to a shorter oil chain so that the remaining component is only the light fraction of the hydrocarbon [8].

\section{Material and Methods}

In this study some material are needed, such as crude oil, formation water, and core. The following shows the material which needed in the laboratory experiment.

\subsection{Crude Oil and Formation Water Sample}

The formation water and crude oil sample used in this study were taken from the same well in HJN Field, at PT Pertamina EP Asset 4 Field Cepu. The following shows the crude oil and the formation water characteristic. 
Table 1. Crude Oil Characteristic

\begin{tabular}{|l|l|}
\hline \multicolumn{1}{|c|}{ Characteristic } & \multicolumn{1}{|c|}{ Value } \\
\hline Density $(\mathrm{gram} / \mathrm{ml})$ & 0.8761 \\
\hline Specific Gravity $60 / 60^{\circ} \mathrm{F}$ & 0.899 \\
\hline API Gravity $\left({ }^{0} \mathrm{API}\right)$ & 25.89 \\
\hline
\end{tabular}

Table 2. Formation Water Characteristic

\begin{tabular}{|l|l|}
\hline \multicolumn{1}{|c|}{ Characteristic } & \multicolumn{1}{c|}{ Value } \\
\hline Density $(\mathrm{gram} / \mathrm{ml})$ & 1.004 \\
\hline Salinity $(\mathrm{ppm})$ & 16.000 \\
\hline $\mathrm{pH}$ & 9.07 \\
\hline
\end{tabular}

\section{2. “U-Champ" Biosurfactant Sample}

"U-Champ" biosurfactant sample is a type of biosurfactant that has been developed by researchers at the Enhanced Oil Recovery Research Laboratory, Department of Petroleum Engineering UPN "Veteran" Yogayakarta. "U-Champ" biosurfactant concentration that used in the experiment are $2.5 \%, 5 \%, 7.5 \%$, and $10 \%$. The following shows the "U-Champ" biosurfactant characteristic.

Table 3. "U-Champ" Biosurfactant Characteristic

\begin{tabular}{|l|l|}
\hline \multicolumn{1}{|c|}{ Characteristic } & \multicolumn{1}{|c|}{ Value } \\
\hline Density $(\mathrm{gram} / \mathrm{ml})$ & 1.1318 \\
\hline
\end{tabular}

\subsection{Core}

The core itself is a core sample made in the laboratory (artificial core) to replace the availability of the original field core, where the physical properties of this artificial core are made to resemble the physical properties of the field core, so that the artificial core sample 
can be used to represent the original field core in laboratory experiment. The following shows the core characteristic that used in the laboratory experiment.

Table 4. Core Characteristic

\begin{tabular}{|l|l|l|l|}
\hline Core & Pore Volume (cc) & Porosity (\%) & Pemeability (mD) \\
\hline $50-15$ & 1.19 & 10.35 & 110.17 \\
\hline $50-17$ & 2.13 & 16.37 & 137.72 \\
\hline
\end{tabular}

\subsection{Methods}

This study is conducted at Enhanced Oil Recovery Research Laboratory at UPN "Veteran" Yogyakarta. Moreover, there are several steps that need to be followed in the laboratory experiment.

\subsubsection{Interfacial Tension (IFT) Measurement}

The IFT measurement was conducted to determine the ability of biosurfactants to reduce the value of the interfacial tension between oil and formation water. Sample of crude oil and biosurfactant "U-Champ" were tested using a spinning drop tensiometer [9]. The measurement using the spinning drop method is carried out by placing a small bubble of immiscible fluid or gas in another fluid, in which case the immiscible fluid is oil and the other fluid is formation water. Then the two fluids are rotated in the horizontal axis. Due to the resulting centrifugal force, the bubble of the immiscible fluid will change its shape to cylindrical according to the value of the interfacial tension, the smaller the value of the interfacial tension, the more cylindrical the resulting shape will be. The temperature used are between $36.5-80^{\circ} \mathrm{C}$.

\subsubsection{Density Measurement}

Density measurement was carried out using a pycnometer and digital scale, this aims to determine the effect of increasing the density of the oil sample after being added by "UChamp" biosurfactant and for input data on the viscosity measurement.

\subsubsection{Viscosity Measurement}

Viscosity measurement was carried out on crude oil sample before and after adding the "UChamp" biosurfactant at several concentrations. This was done to determine the effect of the viscosity of the sample after adding the "U-Champ" biosurfactant and to determine the 
resistance of the "U-Champ" biosurfactant at high temperatures (between $36.5-80^{\circ} \mathrm{C}$ ). The tool used in the viscosity measurement is brookfield viscometer with spindel ULA.

\subsubsection{Imbibition Experiment}

The imbibition test was carried out before the core flooding experiment, which aims to determine the recovery factor without the influence of pressure. Imbibition is a process when the saturation of the wetting phase increases and the non-wetting phase decreases. The wetting phase will enter spontaneously into the porous medium and push the non-wetting phase with capillary pressure. With the entry of water into porous rock that is saturated with oil, the water will push the trapped oil [10]. This test is carried out with core that have been saturated with oil for 4 days, formation water, and "U-Champ" biosurfactant.

\subsubsection{Core Flooding Experiment}

The next step is to conduct core flooding experiment to determine the increase in the oil recovery factor. Core flooding is the implementation of injection activities in the field on a laboratory scale. The core flooding testing process begins with making the initial conditions in the core by carrying out the formation water saturation process by immersing the core in formation water. After that, the oil saturation process is carried out by injecting oil into the core to determine the original oil in place (OOIP) and initial oil saturation (Soi) in the core. The OOIP value of the core can be calculated from the amount of formation water that comes out in the process, because the formation water coming from the core is replaced by injected oil. After that, the "Ú-Champ" biosurfactant injection process was carried out with various soaking times ( 1 hour, 24 hours, and 48 hours) to allow time for the "U-Champ" biosurfactant to react with the fluid. Then, the oil that comes out in this process is also used to calculate the recovery factor and remaining oil saturation (Sor). The final result that will be obtained is the recovery factor, both from water injection and biosurfactant injection. This increase in recovery factor is an important factor in the success of an EOR activity. 


\section{Results and Discussion}

\subsection{Interfacial Tension (IFT) Measurement}

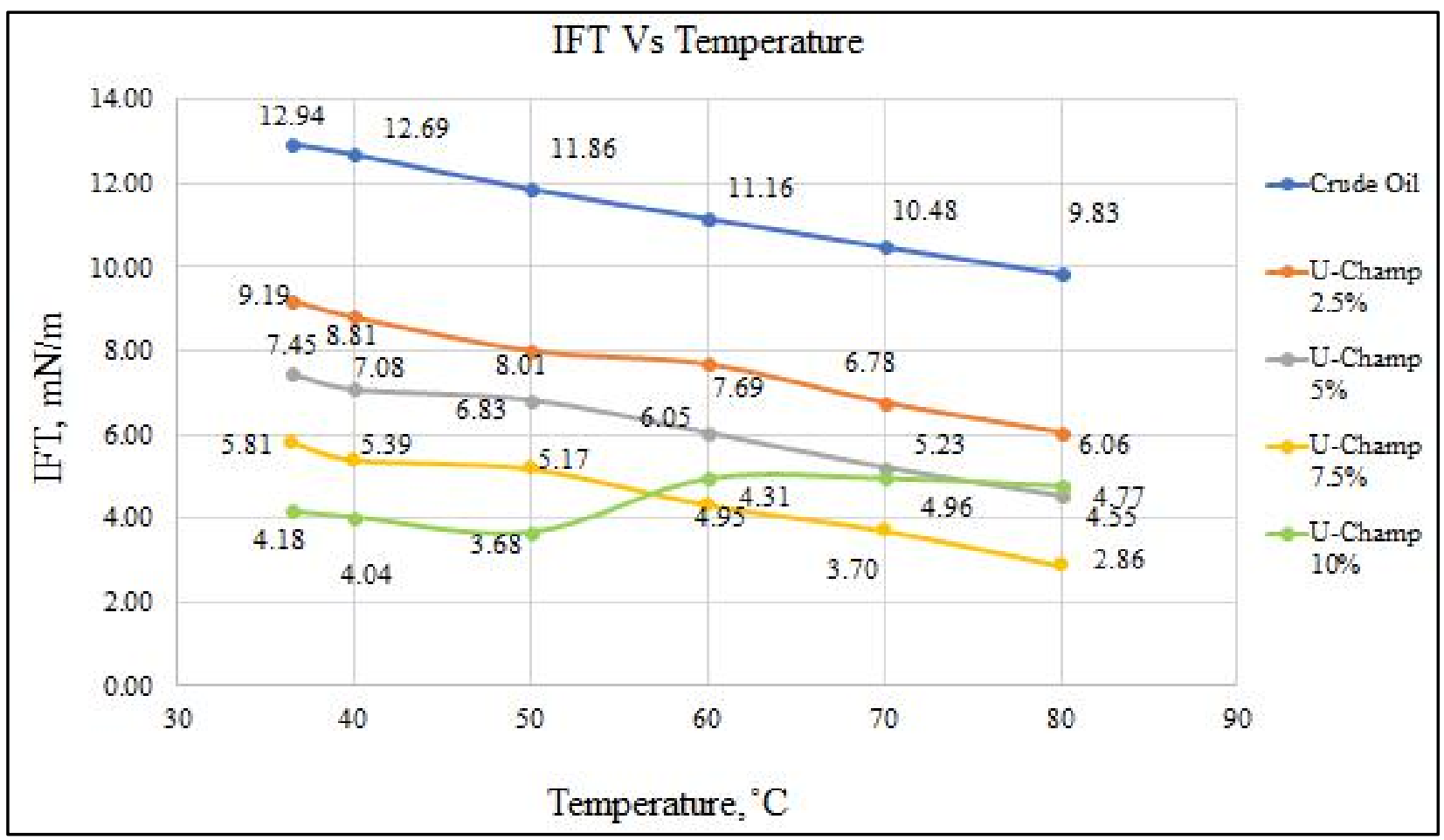

Figure 1. IFT Measurement Result

The lower the IFT value, the easier the oil will flow. This can be seen from the results of observations on a spinning drop tensiometer that works dynamically. The "U-Champ" biosurfactant solution used is a multiple of $2.5 \%$ concentration and with a maximum concentration of $10 \%$. Based on the IFT measurement, the IFT value that gives the maximum reduction value is at a concentration of $7.5 \%$ with an IFT value of $12.93 \mathrm{mN} / \mathrm{m}$ to $5.80 \mathrm{mN} / \mathrm{m}$ at a temperature of $36.5^{\circ} \mathrm{C}$, and an IFT value of $9.83 \mathrm{mN} / \mathrm{m}$ to $2.86 \mathrm{mN} / \mathrm{m}$ at a temperature of $80^{\circ} \mathrm{C}$.

After knowing the IFT value of each temperature and concentration, we can determine the critical micelle concentration (CMC). A concentration of $7.5 \%$ is used as the value of $\mathrm{CMC}$, because at a concentration of $5 \%$ the IFT yield is high, but after a concentration of $7.5 \%$ the value of IFT again increases. The IFT value decreases with increasing concentration of biosurfactant until it reaches $\mathrm{CMC}$, if above the $\mathrm{CMC}$ concentration the IFT decrease becomes insignificant because micelles have formed so that the addition of concentration will not affect the micelles that have been formed, this is due to the biosurfactant "U-Champ" already at the saturation point or critical point. 


\subsection{Density Measurement}

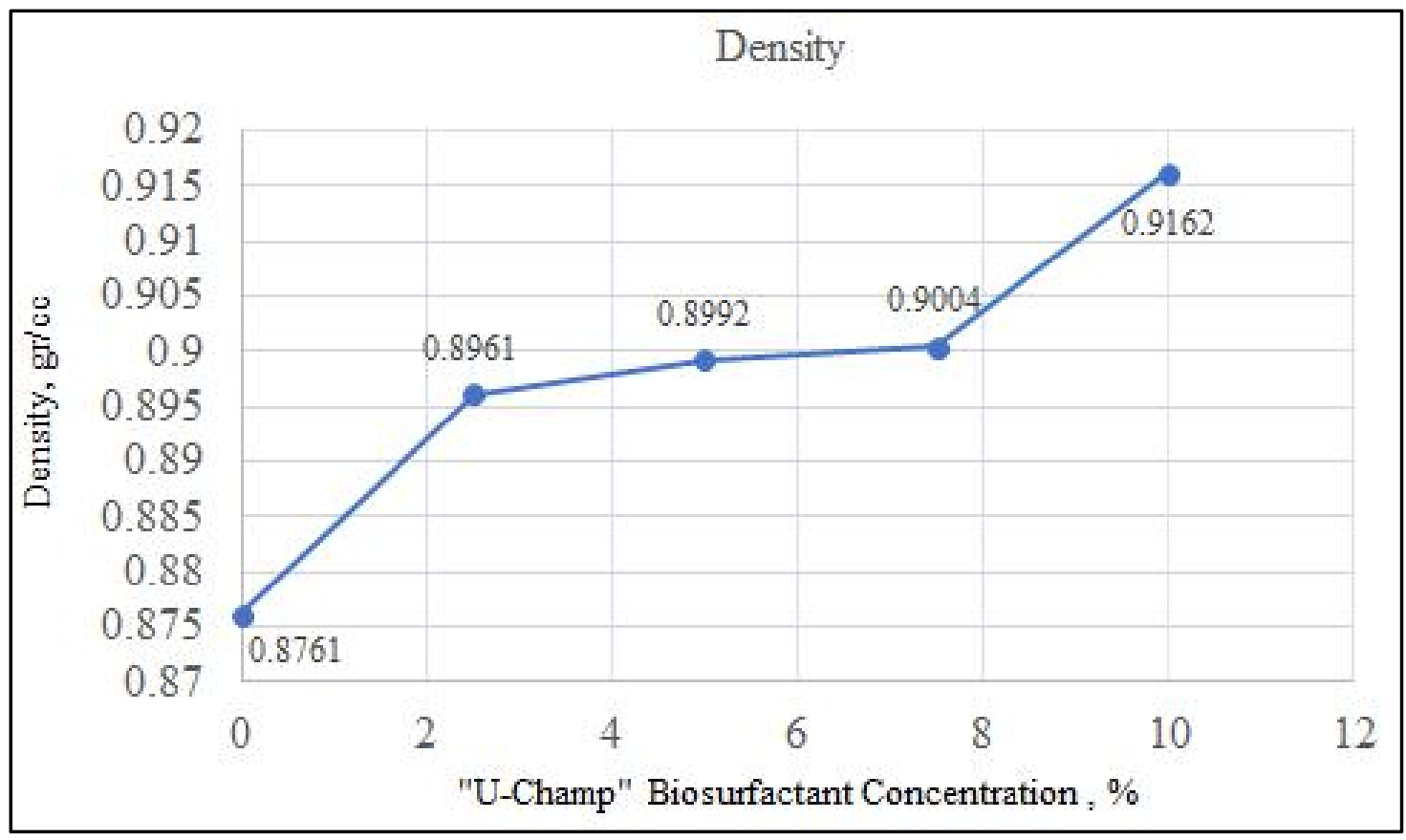

Figure 2. Density Measurement Result

Based on the results of the density measurement of the oil sample with the "U-Champ" biosurfactant treatment, the density of the oil sample will increase with the addition of the "U-Champ" biosurfactant concentration. This is because the density of the biosurfactant is greater than the crude oil, so when mixed the density of the solution increases. So that at a concentration of $10 \%$, it has the greatest density of $0.9162 \mathrm{gr} / \mathrm{ml}$.

\subsection{Viscosity Measurement}

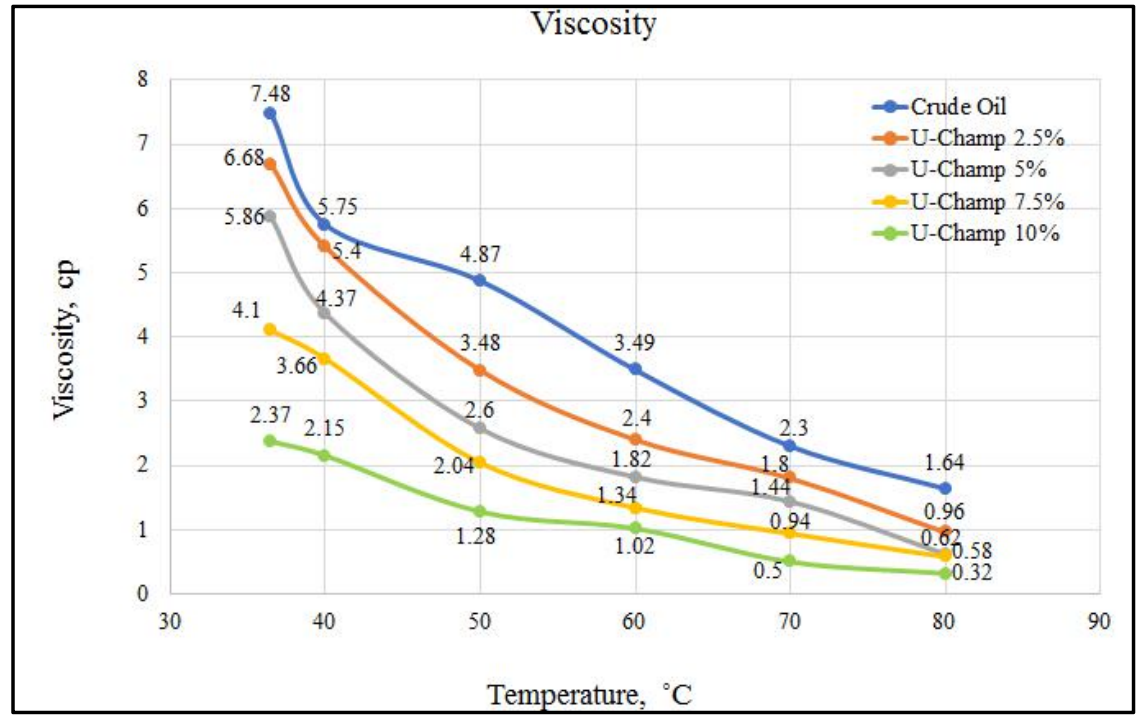

Figure 3. Viscosity Measurement Result 
The temperature used in this measurement starts from of $36.5^{\circ} \mathrm{C}$, because less than that temperature the oil has started to freeze or cannot flow, then the measurements are continued at temperatures of $40^{\circ} \mathrm{C}, 50^{\circ} \mathrm{C}, 60^{\circ} \mathrm{C}, 70^{\circ} \mathrm{C}$, and $80^{\circ} \mathrm{C}$. The concentration of "U-Champ" biosurfactant used was $0 \%, 2.5 \%, 5 \%, 7.5 \%$, and $10 \%$. From the results of the viscosity test, it can be seen that the addition of "U-Champ" solution to the oil sample can reduce the viscosity of the oil. The sample with the addition of 7.5\% "U-Champ" biosurfactant gave a maximum decrease in viscosity from $7.48 \mathrm{cp}$ to $4.10 \mathrm{cp}$ at $36.5^{\circ} \mathrm{C}$ and from $1.64 \mathrm{cp}$ to $0.58 \mathrm{cp}$ at $80^{\circ} \mathrm{C}$. The "U-Champ" biosurfactant reacts with the oil causing the viscosity of the oil to decrease, so that the oil flows more easily. Thus, it can be concluded that this "U-Champ" biosurfactant can be used in the biosurfactant injection process in the HJN Field because the viscosity value decreases at each concentration and temperature.

\subsection{Imbibition Experiment}

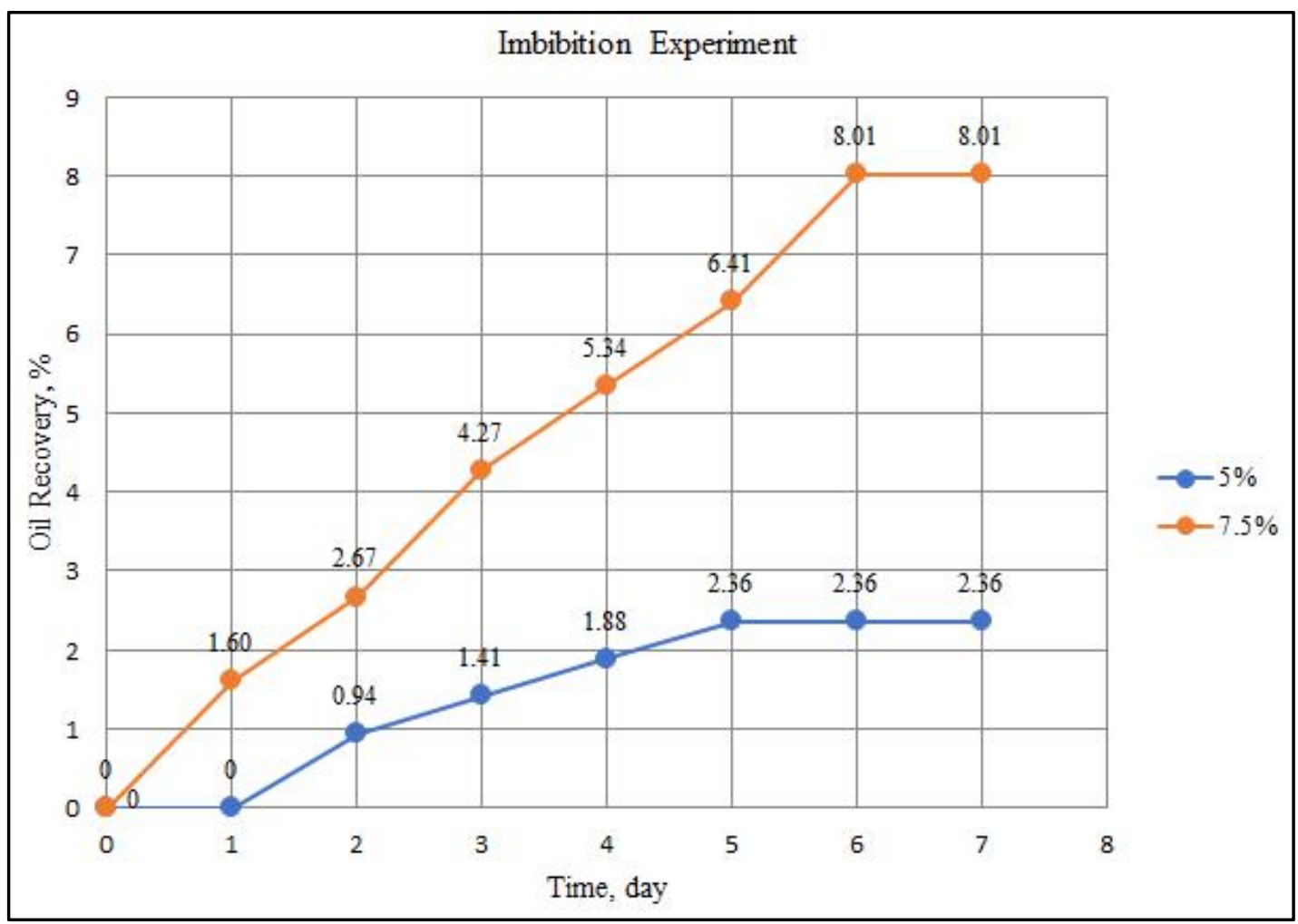

Figure 4. Imbibition Experiment Result

With the imbibition test, we can see how much oil is produced by observing until the oil produced in the tube is stable. The concentration of "U-Champ" biosurfactant used in this experiment is a concentration of $5 \%$ and $7.5 \%$, these concentrations are taken from the concentration which is $\mathrm{CMC}$ and the concentration before $\mathrm{CMC}$ value. This experiment used two concentrations because to ascertain which of the two concentrations produces a higher 
recovery factor so that it can be used for the core flooding experiment. The imbibition experiment used core 50-17 for a concentration of 5\% and core 50-15 for a concentration of $7.5 \%$. Based on the observations, the recovery factor with the concentration $7.5 \%$ is higher than the concentration of $5 \%$, which is $8.01 \%$. So that the concentration of "U-Champ" biosurfactant is $7.5 \%$ which will be used for core flooding experiment.

\subsection{Core Flooding Experiment}

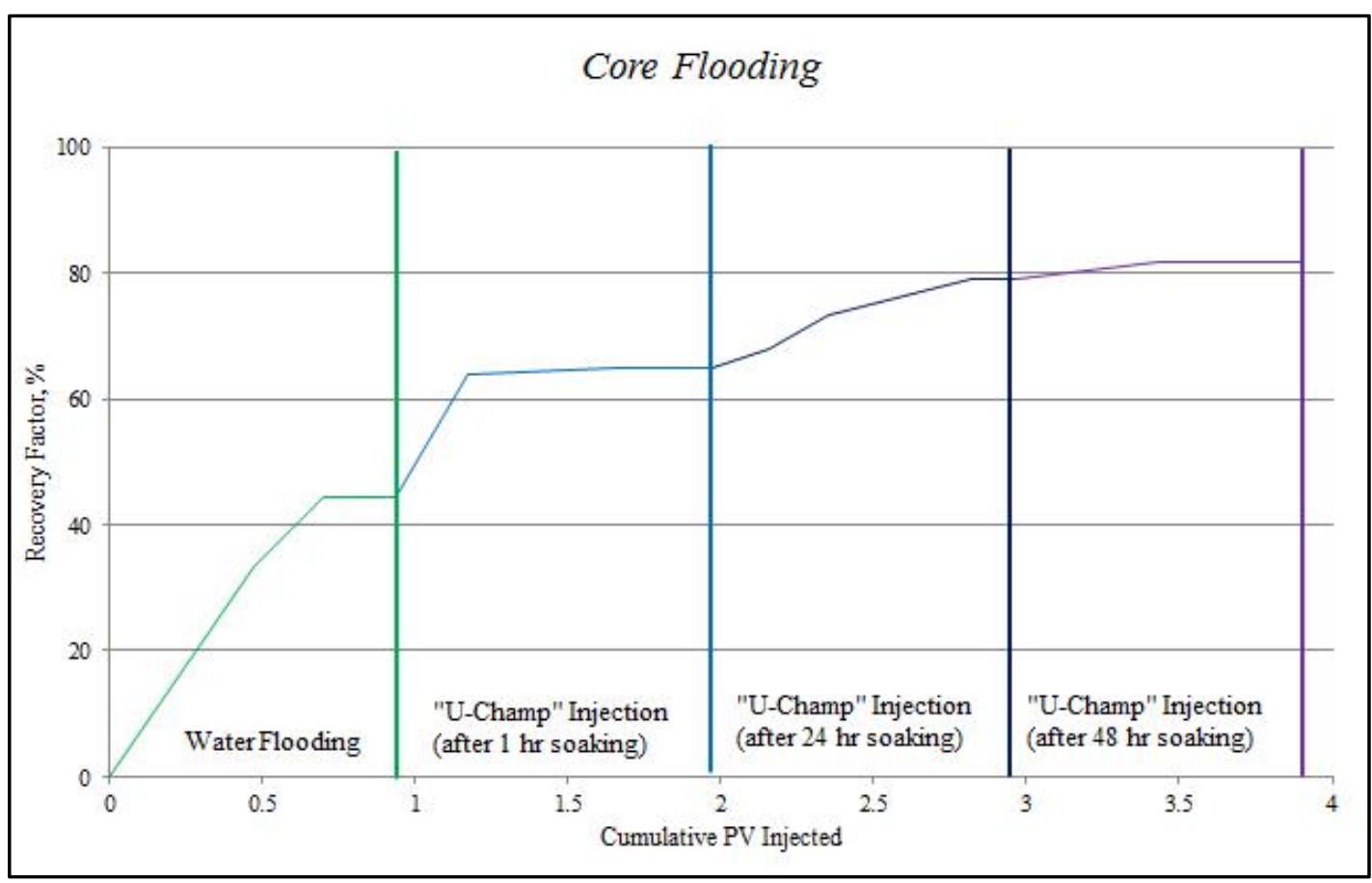

Figure 5. Core Flooding Experiment Result

The core flooding experiment used a series of core flooding tools, which the confined pressure is set to 120 psig to prevent fluid leakage in the core holder. The fluid is injected through the core pores in the core holder, then the fluid that comes out is accommodated in a measuring tube below the outlet. The volume of the fluid that comes out is measured as a result of the core flooding experiment. The core 50-17 is used in this experiment. Based on the results of the oil saturation stage, the OOIP obtained was $1.8 \mathrm{cc}$ with Soi of $84.59 \%$ and Swi of $15.41 \%$. At the water flooding stage, it has a recovery factor of $44.44 \%$ and a Sor of 0.47. The core used can be continued to the biosurfactant injection stage "U-Champ", because it has a recovery factor value of $25-50 \%$.

Furthermore, the injection process of "U-Champ" biosurfactant with a concentration of $7.5 \%$ was carried out, the recovery factor was added and the Sor decreased for each soaking time. In the results after 1 hour soaking time, the recovery factor is $20.56 \%$ and the Sor is 0.67 , 
with a total PV injected pore volume of 1.03. The injected of 1.03 PV means the limit, so that not too much biosurfactant was injected from the core pore volume. In the results after a 24 hours soaking time, the recovery factor is $13.89 \%$ and the Sor is 0.73 , with a total PV injected of 0.99 . In the results after 48 hours soaking time, the recovery factor is $2.78 \%$ and Sor is 0.82 , with a total PV injected of 0.94 . After obtaining the recovery factor value at each core flooding stage, a cumulative data table can be made. The last recovery factor value at the time of injection of biosurfactant "U-Champ" after soaking time for 48 hours was $81.67 \%$, So was 0.16 , and $\mathrm{Sw}$ was 0.84 . Judging from the value of the recovery factor that continues to increase, soaking time is able to facilitate the release of oil attached to the core so that it is produced. Laboratory experiment at the EOR production stage resulted in an average recovery factor of $70-90 \%$, so it can be said that this experiment was successful.

From the series of studies conducted, it can be seen that the addition of the "U-Champ" biosurfactant solution can change the characteristics of the reservoir fluid and cause an increase in the oil recovery factor. The use of the "U-Champ" biosurfactant solution is suitable for use in reservoirs that have the same or similar characteristics as fluid samples from the HJN Field.

Table 5. Core Flooding Experiment

\begin{tabular}{|c|c|c|c|c|c|c|c|c|c|c|c|}
\hline Tube & $\begin{array}{l}\text { Total } \\
\text { Vol. } \\
(\mathrm{ml})\end{array}$ & $\begin{array}{c}\text { Water } \\
\text { Vol. } \\
(\mathrm{ml})\end{array}$ & $\begin{array}{l}\text { Oil Vol. } \\
\text { (ml) }\end{array}$ & WC (\%) & $\begin{array}{c}\text { Cumulative } \\
\text { PV } \\
\text { Injected }\end{array}$ & $\mathrm{RF}(\%)$ & $\begin{array}{l}\text { Oil Vol. } \\
\text { Cumulative } \\
\text { (ml) }\end{array}$ & So & Sw & $\begin{array}{c}\text { PV } \\
\text { Inject } \\
\text { ed }\end{array}$ & $\begin{array}{c}\text { Cumulative } \\
\text { PV Injected } \\
\text { in Each } \\
\text { Steps }\end{array}$ \\
\hline & 0 & 0 & 0 & 0 & 0 & 0 & & & & & \\
\hline WF1 & 1.00 & 0.40 & 0.60 & 40.00 & 0.47 & 33.33 & 0.60 & 0.56 & 0.44 & 0.47 & \multirow{3}{*}{0.94} \\
\hline WF2 & 0.50 & 0.30 & 0.20 & 60.00 & 0.70 & 44.44 & 0.80 & 0.47 & 0.53 & 0.235 & \\
\hline WF3 & 0.50 & 0.50 & 0.00 & 100.00 & 0.94 & 44.44 & 0.80 & 0.47 & 0.53 & 0.235 & \\
\hline BF1-1 & 0.50 & 0.15 & 0.35 & 30.00 & 1.17 & 63.89 & 1.15 & 0.31 & 0.69 & 0.235 & \multirow{3}{*}{1.03} \\
\hline BF1-2 & 1.00 & 0.98 & 0.02 & 98.00 & 1.64 & 65.00 & 1.17 & 0.30 & 0.70 & 0.47 & \\
\hline BF1-3 & 0.70 & 0.70 & 0.00 & 100.00 & 1.97 & 65.00 & 1.17 & 0.30 & 0.70 & 0.329 & \\
\hline BF $24-1$ & 0.40 & 0.35 & 0.05 & 87.50 & 2.16 & 67.78 & 1.22 & 0.27 & 0.73 & 0.188 & \multirow{4}{*}{0.99} \\
\hline BF $24-2$ & 0.40 & 0.30 & 0.10 & 75.00 & 2.35 & 73.33 & 1.32 & 0.23 & 0.77 & 0.188 & \\
\hline BF24-3 & 1 & 0.90 & 0.10 & 90.00 & 2.82 & 78.89 & 1.42 & 0.18 & 0.82 & 0.47 & \\
\hline BF $24-4$ & 0.3 & 0.30 & 0.00 & 100.00 & 2.96 & 78.89 & 1.42 & 0.18 & 0.82 & 0.141 & \\
\hline BF48-1 & 1 & 0.95 & 0.05 & 95.00 & 3.43 & 81.67 & 1.47 & 0.16 & 0.84 & 0.47 & \multirow{2}{*}{0.94} \\
\hline BF 48-2 & 1 & 1.00 & 0.00 & 100.00 & 3.90 & 81.67 & 1.47 & 0.16 & 0.84 & 0.47 & \\
\hline
\end{tabular}




\section{Conclusion}

It was concluded from this study that:

1. "U-Champ" biosurfactant is proven to be used as an injection fluid to increase the oil recovery factor, this is shown in the IFT and the viscosity experiment which shows a significant decrease in value.

2. The smaller the IFT value, the higher the increase in the oil recovery factor. This was proven in the imbibition test with 2 concentrations (5\% and $7.5 \%$ ), concentration of $5 \%$ had an IFT value of $5.23 \mathrm{mN} / \mathrm{m}$ and RF of $2.36 \%$, while the concentration of $7.5 \%$ had an IFT value of $3.70 . \mathrm{mN} / \mathrm{m}$ and $\mathrm{RF}$ of $8.01 \%$.

3. The results of the core flooding experiment showed an increase in the oil recovery factor, as indicated by the increase in RF from $44.44 \%$ (water flooding) to $65 \%$ (after soaking time of 1 hour). And Sor reduced from 0.47 to 0.30 .

4. The longer the soaking time, the better the result of increasing the oil recovery factor. It is shown that after soaking time for 24 hours it has an RF of $78.89 \%$, Sor 0.18 and after soaking time for 48 hours it has an RF of $81.67 \%$, Sor 0.16 .

\section{Acknowledgement}

This paper is fully supported by Ministry of Research, Technology and Higher Education of the Republic of Indonesia (KEMENRISTEKDIKTI RI) and the Research and Community Service (LPPM) UPN "Veteran” Yogyakarta, in the 2021 PTUPT RISTEKDIKTI. We would also like to thank PT Pertamina EP Asset 4 Field Cepu for providing the material that used in this study.

\section{References}

[1] Gomaa, Ezzat. E. (2015). “Enhanced Oil Recovery Concepts and Mechanism”. In House Training Course EOR - Pertamina EP, Jakarta, 26-28 Oct. pp. 8,10.

[2] Eldeen, Ahmed E.G., Alhadi, Al Mustafa A.A., \& Mergani, Mohamed A. 2013. “Microbial Enhanced Oil Recovery (MEOR)”. Sudan : University of Khartoum. pp. 4.

[3] Sulistyarso, H.B., Pamungkas, J., Gusmarwani, S.R., Widyaningsih, I., \& Kurnia, R.A., 2020. “Application of Bio-surfactants as an Effort to Enhanced Oil Recovery (EOR) in 
Kawengan Oil Field". American Institute of Physics (AIP) Conference Proceedings., 2nd International Conference on Earth Science, Mineral, and Energy, 2245. pp. 1.

[4] Rabiei, A., Sharifnik, M., Niazi A., Hashemi A., \& Ayatollahi S. 2013. "Core Flooding Test to Investigate The Effects of IFT Reduction and Wettability Alteration on Oil Recovery During MEOR Process in an Iranian Oil Reservoir. Applied Microbial Biotechnol, Vol. 97. pp. 5980, 5988.

[5] Bordoloi, N.K., \& Konwar, B.K. (2007). "Microbial Surfactant-Enhanced Mineral Oil Recovery Under Laboratory Conditions. India : Colloids and Surfaces Biointerfaces, Vol. 63. pp. 73.

[6] Sulistyarso, H.B., Pamungkas, J., Widiyaningsih, I., \& Wahyuningsih, T. 2020. "Biosurfactan Injection of "U-Champ" on Heavy Oil Sample in Laboratory for Pleminary to Pilot Project". International Journal of Recent Technology and Engineering (IJTRE) : Blue Eyes Intelligence Engineering and Sciences Publications. pp. 46.

[7] Sen, R. 2008. "Biotechnology in petroleum recovery: The microbial EOR". Energy and Combustion Science. pp. 717.

[8] Purwasena, I.A., Sugai, Y. \& Sasaki, K. 2009. "Estimation of the Potential of an OilViscosity-Reducing Bacteria, Petrotoga sp., Isolated from an Oilfield for MEOR". International Petroleum Technology Conference. pp. 1.

[9] Sulistyarso, H.B., Pamungkas, J., Gusmarwani, S.R., \& Wahyuningsih, T., 2019. "Aplikasi Biosurfaktan dalam Upaya Peningkatan Perolehan Minyak Tahap Lanjut: Uji Laboratorium pada Sampel Sumur KW-58”. Yogyakarta: Prosiding SNCPP 2019 "Pengembangan Ristek dan Pengabdian Menuju Hilirisasi Industri" LPPM UPN "Veteran" Yogyakarta. pp. 56.

[10] Woe, K., Setiati, R., Fattahanisa, A., \& Alli, Yani F. 2019. "Studi Karakteristik Larutan Surfaktan dengan Imbibisi Spontan pada Lapangan "K”, Sumatera Selatan”. Seminar Nasional Cendekiawan, Vol. 5. pp. 2. 